\title{
Wedding Culture Traditional Wedding Traditions Pujud Rokan Downstream Riau
}

\author{
Khori Pilihan', Dr. Aman, M.Pd² \\ Universitas Negeri Yogyakarta, jl. Colombo No 1 Karang Malang \\ khoripilihan012@gmail.com¹,Aman@uny.ac.id²
}

\begin{abstract}
One of the most important phases in human life in the community is marriage because it can change legal status and as a social reality because there is not only a bond between husband and wife but there is also a kinship bond between the families of the bride and groom, including the ethnic groups and communities in it. This study was carried out in Pujud Sub-District Rokan Hilir Regency Riau Province to explore the stages of Malay Pujud Wedding.
\end{abstract}

Keywords: culture, Malay Pujud, customs

\section{Introduction}

Indonesia has a variety of cultures, one of which is a wedding in a variety of unique ways because each tribe has its own way of the wedding. In addition, the wedding culture in Indonesia has its own philosophy. Marriage is not only based on love but involves the physical and mental of both the bride and groom. When they have married, they automatically enter into a new life with all the consequences. Marriage is a sacred bond that can unite body and soul between men and women under the protection of the law and under the auspices of the one and only God. Happiness in a marriage is the dream of every human being, therefore marriage is viewed as a very sacred, important, and serious one because there is preparation in terms of social, economic, physiological, and psychological life. In a marriage, several couples do not realize the need for readiness (Zein \& Suryani, 2005). In a Nias culture wedding, the kinship of the bride and groom is formed. (Kontjaraningrat, 1980: 90) explained that marriage is one of the very important phenomena in human life because marriage aims to regulate sex and provide protection for children of marriages. In addition, marriage is one way to meet the needs of a life partner, property, prestige, social status in society, and as well as maintaining relationships between relatives.

One of the most important phases in human life in the community is marriage because it can change legal status, for example, someone who is not considered "adult" by carrying out a marriage will be considered an "adult" or previously someone who is still considered a young person but after carrying out the marriage, they will become a husband and wife with various sociological and juridical consequences (Windi, 2019: 10). Therefore, marriage is one of the social realities in society. Marriage is called social reality because there is not only a bond between husband and wife but there is also a kinship bond between the families of the bride and groom, including the ethnic groups and communities in it. Based on the previous research entitled "Malay Riau Culture in developing a civic culture" where culture is a collection of knowledge, beliefs, arts, law, morals and customs from the abilities and habits that are obtained from someone as a member of society (Horton \& Chester, 1996). Based on the thoughts of many experts, cultural diversity is obtained through the learning process and 
culture can be described from the biological, sociological and psychological components, namely from human existence. Culture is structured, culture contains several aspects, and culture is dynamic. (Wiranata, 2011) stated that there are four main elements of culture, namely technology, economic system, family, and political power. (Melville J. Herkovits) stated that four elements include elements of social norms that allow cooperation between members of society to adapt to their surroundings, the tools and institutions around them, economic organization, and political power.

Marriage is one of the inner bonds between husband and wife to form an eternal family or household based on "Belief in the One and Only God" (Law Number 1 of 1974). Marriage is declared valid if it meets the conditions of marriage which are carried out based on the respective laws of each religion. Customs can experience a dynamic development process because customs are identical and synonymous with culture, which is a way of life (Ramli, 2006). The compliance of the Malay people can be described to below:

$$
\begin{aligned}
& \text { “adat berwaris pada nabi } \\
& \text { Berkhafilah pada Adam } \\
& \text { Adat berinduk ke Ulama } \\
& \text { Adat tersirat dalam sunnah } \\
& \text { Adat dikungkung kitabullah } \\
& \text { Itulah adat yang tahan banding } \\
& \text { Itulah adat yang tahan asak" }
\end{aligned}
$$

Malay customs certainly have a strong foundation, namely the Qur'an and hadith (Suwardi et al, 2015). The Indonesian people are more aware of the customs brought from birth and the customary laws of their place of residence, for example, the Bugis people must know the Bugis customs, the Javanese must know Javanese customs and the Malay people must know Malay customs and so on. However, in the development of customs, only certain people or organizations know about it, where they still remember the customs of the previous generation, especially at weddings. Malay Ujung Batu Riau Wedding has several stages including namely:

a) Pre-Wedding Stage: Sulur air (merisik or meninjau), Mempa'al (merasi), masuk suku/mengambil suku,

b) Wedding Stage: Opening the tepak tanda (antar tanda/memimang or engagement), anatar Belanja/antaran, marriage contract, worship, khatam Al-qur'an, berinai, tepung tawar, praying. This study was carried out in Pujud Sub-District, Rokan Hilir Regency Riau for 3 weeks. This study chose 6 respondents who know better about the Malay Pujud cultural wedding customs such as the Ninik Mamak, 11 tribes, or the Malay Pujud Tribal Chief, using the qualitative method.

\section{Research Method}

This study used a naturalistic qualitative approach because the situation in the field is natural as it is and not manipulated. This study was expected to obtain natural data where the expression is likely to be natural and without manipulation. This study was carried out in Pujud Sub-District, Rokan Hilir Regency Riau and the subjects of this study were Tribal Chief dan ninik mamak of Malay Pujud. This study used natural data or primary data sources where 
data collection was based on the observation of the Malay Pujud Wedding and the interview of the Tribal Chief and ninik mamak of Melayu Pujud. In addition, data were found in books. (Sugiyono,2018:106

\section{Results And Discussion}

Text formatting, Based on the results obtained and recommendations from the interviews and considerations in the field, the stages of the Malay Pujud wedding are as follows

\subsection{Customs in Wedding}

Marriage is regulated in the customs as states in a proverb " hidup di kandung adat mati di kandung tanah".

\subsection{Engagement Procession}

Sulur-sulur Air, The groom goes to the bride with the following process:

a) The Groom said, "It seems that there is a woman who is not married if no one has proposed, we want to propose, so it is the intention of our visit".

b) The family of the bride replied, "it's true that you say we have a daughter, nobody has proposed yet, but even though it is like that, we cannot decide now, so let us discuss with the family first. Whatever the decision, tomorrow we will answer".

\subsection{Reception Meeting}

Reception meeting is a meeting held by the women together with ninik mamak and inviting the closest family, cerdik pandai, religious scholars, and the local government. This meeting aims to decide the proposal from the groom that has been conveyed through the sulursulur air, the processes are as follows:

a) Sumondo gave a tepak to mata buah perut "Mamak, a few days ago there was a Malay tribal child who wanted to propose so we could not give an answer again, or " anak kami punya anak kemenakan mamak punya". (Sumondo)

b) Mata buah perut gave tepak to induk

c) Induk gave tepak to tongkat

d) Tongkat gace tepak to pucuk suku

e) Ask permission from the local government.

After the permission is obtained, the poll is carried out and then the results of the meeting are concluded according to the proverb "bulat air karena ada pembuluh, bulat kata karena mufakat" then the proposal is accepted with all the considerations as in a proverb "tertangkap ikan sama-sama ketawa, dapat ular sama cakar" which means if in the future something undesirable happens, then it should be a shared decision.

\subsection{Returns the Word}

After Reception meeting, the mengembalikan kata is carried out. Mengembalikan kata is carried out day or night by the wife of ninik mamak from the bride and several other family members to the house of groom for a maximum period of a week. If the proposal is accepted, 
the person who does mengembalikan kata must multiply the number of the word delivered. If the proposal is rejected, then the person who does mengembalikan kata should be fewer. After mengembalikan kata, the antaran is carried out.

\subsection{Proposal}

2 tepak must be provided namely tepak tanda from carved areca nut and tepak tanda for ninik mamak, proposal can only be made by the wife of ninik mamak from the groom and ninik mamak from the bride, at least by mata buah perut of both sides and attended or witnessed by the local government at least the Head of RT / RW. Codes in Ulang-ulang Signs with areca nut indicate that the marriage ceremony will have to slaughter the goat. The spokesperson at the time of the proposal must be carried out by the wife of the tribal head or vice versa.

\subsection{Hantaran}

The amount of antaran agreed in the customary meeting is Rp1,500,000, -. (One Million Five Hundred Thousand Rupiah)

\subsection{Wedding}

Provisions On Wedding Are As Follows Dowry:

a) Dowry is not stipulated in customs, according to the agreement of both parties.

b) For ninik mamak, both parties are Rp. 100,000, - (One Hundred Thousand Rupiah).

c) For two witnesses Rp. 100,000, - (One Hundred Thousand Rupiah).

d) The wedding is arranged according to custom by the ninik mamak.

e) After the solemnization of a marriage, the bride is to the left of the groom.

f) Listen to promises from the groom.

g) Give the dowry to the bride.

h) After that, the bride returned to the original aisle.

\subsection{Stages in Wedding}

a) First of all, the parents of the bride and groom tell ninik mamak about the wedding schedule.

b) Then the ninik mamak of the bride negotiates with the ninik mamak of the groom.

c) If it has been agreed, if possible, a work meeting is held to discuss the wedding.

d) Invitation to a work meeting held by the parents of the bride and groom.

e) In meetings, parties that must be invited are: Relatives, sumondo, datuk penghulu, families, friends, and important people.

\subsection{Pairs of Slag (Togak Pancu)}

Togak pancu is implemented if it has received permission fromninik mamak at least mata buah perut/mamak suku, for tegak tiang must be implemented by ninik mamak at least mata bawah perut. Implemented in gotong royong who willingly help. 
If there is a feast that does not make it possible to accommodate the guests at the implementation of the meeting, then the feast hosts can make a pancu first by asking permission to ninik mamak.

\subsection{The Aisle}

Carrying out work and soaking rice can be performed if it has been attended by the wife of ninik mamak and if there are obstacles at least can be replaced by buah mata perut.

\subsection{Wedding Ceremony}

a) Organized by ninik mamak.

b) Wedding ceremony time is allowed in the morning, day, and night.

c) The parents accompany the bride

\subsection{Entertainment}

Entertainment to enliven the feast is held along the appropriate ways with the permission and approval of ninik mamak.

\subsection{The Pickup of Sudah Siang Groom}

Picked up by the bride, accompanied by 2 children. Bridal pickup equipment:

a) Sepengadak (sepersalinan) dress which is equipped with a dagger, umbrella and a bridal fan

b) Tepak sirih

c) Equipment to pick up the bride is neatly wrapped

d) The picker is dressed in Malay completely/samping

Parading equipment for Pengantih Sudah Siang
a) Tepak sirih
b) 1 Gulung tikar which consists oflarge pillow wrapped in betel
c) Code on the number of pillows ongulung tikar besar are:
d) 11 pieces then the banquet is a buffalo or cow
e) 9 pieces the banquet is a goat
f) 7 pieces then the banquet is as best the groom could.

Order of Bridal Pickup Tepak, Gulung Tikar, Gulung Tikar Besar, Dulang, Balai Pengantin, and Pengiring. The Groom Comes To The Home of Bride, when the groom comes to the house of the bride, the arrival of the groom is greeted with pencak silat. During the pencak silat event, the groom and the bride are separated and do not live next to each other when giving souvenirs to pencak silat players in front of them. The bride and groom do not get close because they have not implemented the solemnization of a marriage.

\subsection{The Bridal Entourage Welcoming Ceremony}

a) The bridal entourage is welcomed with yellow rice by the wife of ninik mamak/sumondo

b) After the bridal entourage enters the pancu, ninik mamak does a tegur sapa (tepak)

c) The group is received by ninik mamak of the bride. 
Air Belimau/Tepuk Tepung Tawar, parties involved in tepuk tepung tawar are:

a) Datuk Munao/Timbalan

b) Camat

c) Headman

d) Datuk-datuk pucuk suku from 11 tribes

e) Sumundo from the bride and groom

f) Parents of the bride and groom

g) Close relative of the bride and groom.

Khatam Kaji and Bersandingan Pengantin Organized by ninik mamak.

\subsection{Big banquet}

Big banquet is attended by camat, datauk penghulu, headman and local officers, anak kemenakan, sumondo and other invitations arranged by the ninik mamak as feast hosts with the following guidelines:

a) In the right, there are datuk munao, camat, and headman

b) In the left, there are datuk munao, pucuk suku, and sumondo from the oldest pucuk.

c) The dish is opened by niece (anak kemenakan), sumundo dress neatly with long sleeves, wear samping cloth, and wear peci

d) The order of dishes is set as it should start from hand washing water, drinking water, dishes, rice, side dishes, and other dishes.

e) It is first served for Datuk penghulu/headman.

\subsection{Petauh Petakek}

Petuah petakek is still carried out even though the feast is finished at night.Petauh petakek is carried out by ninik mamak, parents, sumondo, and family of the bride and groom. The bridal entourage first reports to the mother with the intention to bring the bride to worship the pucuk. The mother mentions to ninik mamak the place of sumondo. Ninik mamak sumundo mentions that to Datuk Penghulu (goverment officers). Urutan yang di jalani untuk menyembah:
a) Pucuk suku of sumondo
b) Datuk penghulu/government officers
c) Old Sumondo
d) Relatives
e) The groom and the bride custody by ninik mamak of the bridal
f) Upah-upah and words of advice for brides.

\subsection{Time Discipline in Feast}

a) The host determines the time so the invited guest must come when the feast starts

b) Invited guests must be present half an hour before the event begins

c) At the feast, the receptionist should be prepared to arrange the guests in the seats

d) The appointed officer assigned is given a transportation fee of $\mathrm{Rp} \mathrm{100,000} \mathrm{per} \mathrm{vehicle.}$

\subsection{Bridal dress}

The dresses worn by the bride and groom that have been set by custom are: 
a) The Groom, Dress for wedding ceremony is complete Malay dress/samping., dress for tepuk tepung tawar is complete johor dress

b) The Bride, Long kebaya and scarf worn onwedding ceremony and tepung tawar. in mandi belimau and apada patuah, the bride uses inner kebaya, In bertandang it is permissed to use baju kurung, inner kebaya, and mini kebaya.

\section{Conclusion}

Based on the results, it can be concluded thatMalay Pujud Wedding in Rokan Hilir Riau is part of the ninik mamak culture of mutual friendship, mutual cooperation, and so on and various kinds of stages that must be passed by the two prospective brides.

\section{References}

[1] Budaya Adat Penganten Melayu Riau Dalam Pengembangan Budaya Kewarganegaraan. Yosi Kumalasi, Cecep Dermawan. Program Study Pendidikan Kewaganegaraan Sekolah Pasca Universitas Indonesia.

[2] Dahnial, 2014. Hukum Adat, Saksi Adat, Tata Urut Nikah Kawin. Pekanbaru.

[3] Degradasi Budaya Dalam Upacara Perkawinan Masyarakat Nias Denpasar Adil Niat Gulo fakultas Sastra Universitas Udagana

[4] Konseling Pranikah Sebuah Upaya Jurnal Konseling Indonesia Budaya PernikahanPernikahan Dini di kecamatan Pulong Kabupaten Ponorogo Http// ejournal.unikama.ac.id./index.php/JKI. Volume 3 No. 1Oktober 2007

[6] Sugiyono. 2018. Metode Penelitian Kualitatif. Bandung: alfabeta

[7] Interview with M Yunus Pujud

[8] Interview with Mail Pujud

[9] Interview with Bahrudin Pujud

[10] Interview with Kamar Pujud

[11] Interview with Bahtiar Pujud

[12] Interview with Zulkifli Pujud 